\title{
Defining the Editorial Policies of Open Access Journals in Serbia and the Role of Librarians in This Process
}

\author{
Milica Ševkušić \\ Institute of Technical Sciences of the Serbian Academy of Sciences and Arts, Belgrade \\ biblioteka@itn.sanu.ac.rs
}

\begin{abstract}
The paper discusses the process of devising an editorial policy template intended for Serbian Open Access journals and the role of librarians in this process. The template was developed with the idea to provide assistance to journals involved in the reapplication process in the Directory of Open Access Journals, as well as to those intending to apply for indexing in the Web of Science and Scopus. This ready-made solution has a modular structure and it covers the publication ethics, editorial and publishing procedures, and rights. Librarians also provided assistance in the process of aligning journal policies with the offered template. An early result of these actions is the positive outcome of the reapplication process for all journals that defined their editorial policies relying on the proposed template. The paper also identifies the future challenges associated with the implementation of the newly defined policies.
\end{abstract}

Keywords: Open Access journals, Serbia, editorial policy, Directory of Open Access Journals (DOAJ), Committee on Publication Ethics, peer review, copyright, Creative Commons licenses, article processing charge

\section{Introduction}

The editorial policy of a journal is basically a set of rules and guidelines that govern the editorial and publishing processes with the aim of ensuring the maximum quality of the published articles and discouraging and eliminating misconduct. ${ }^{1 *}$ Nowadays, this is usually a publicly available document, or even a set of documents, meant to inform potential authors, as well as readers, about the ethical principles and editorial and publishing procedures applied by the journal. ${ }^{2}$ In the past, statements on editorial policies were more commonly found in editorials or author guidelines. ${ }^{3}$ Along with providing guidance to authors, editors and reviewers, ${ }_{1}^{4}$ editorial policies are also one of the factors evaluated when judging the quality of a journal. In the age of print journals, elements of the editorial policy (e.g. publication frequency, peer review, the quality of the editorial staff) were analyzed by librarians in the process of making subscription decisions. ${ }^{5}$ Nowadays, they are evaluated by bibliographic databases and aggregators, including

\footnotetext{
$1 *$ The paper is a result of the EIFL-funded project Revisiting Open Access Journal Policies and Practices in Serbia, authored and coordinated by the author of the paper and implemented by the Department of Scientific Information of the National Library of Serbia between 22 March 2016 and 22 January 2017. The author would like to thank to Zorica Janković, University of Belgrade, Institute for Biological Research "Siniša Stanković", who was a member of the project team and was involved in the process of devising the policy template.

2 The plural form, editorial policies, is also used to designate the rules and guidelines of a single journal, as they may include distinct sets of rules relevant to particular issues (e.g. privacy issues, research involving animals or human subjects, etc).

3 A C Weller, "Editorial Policy and the Assessment of Quality among Medical Journals", Bulletin of the Medical Library Association 75, no. 4 (October 1987): 310-316

${ }^{4}$ Lois DeBakey, The Scientific Journal: Editorial Policies and Practices: Guidelines for Editors, Reviewers, and Authors (C. V. Mosby Co., 1976).

5 A. C. Weller, "Editorial Policy and the Assessment of Quality among Medical Journals".
} 
the Web of Science ${ }^{6}$ and Scopus. ${ }^{7}$ The analysis of editorial policies may also be instrumental in tracking specific trends in various disciplines. ${ }^{8}$

No matter how concise or detailed an editorial policy may be, it should define the following issues:

- the responsibilities of the participants in the editorial and publishing processes;

- the relevant ethical standards;

- the procedures (peer review, screening for plagiarism, dealing with misconduct and retraction, etc);

- rights (copyright and user rights).

In Open Access (OA) journals, the editorial policy should also contain an Open Access statement. Furthermore, the policy provisions associated with copyright and user rights should be defined in greater detail. ${ }^{9}$ Unlike subscription-based journals, which usually require copyright to be transferred to the publisher, some OA journals allow authors to retain copyright ${ }^{10}$ and most OA journals allow both authors and third parties to reuse the published content. User rights are usually defined using Creative Commons or similar licenses. ${ }^{11}$ Data sharing policies are becoming increasingly topical, as well. ${ }^{12}$ The transparency of editorial policies in OA journals is highlighted in the Principles of Transparency and Best Practice in Scholarly Publishing, a document jointly drafted by the Committee on Publication Ethics (COPE), the Directory of Open Access Journals (DOAJ), the Open Access Scholarly Publishers Association (OASPA) and the World Association of Medical Editors (WAME). The principles largely draw on the criteria developed by DOAJ. ${ }^{13}$

It is particularly important for OA journals to have a clearly defined editorial policy because they are often exposed to the risk of being ostensibly identified as "predatory". ${ }^{14}$ In the "Criteria for Determining Predatory Open-Access Publishers", Jeffrey Beall listed a number of policy-related issues, such as the lack of license information or poor understanding of licensing standards, no retraction policy and/or retracting articles without a formal statement, false claims regarding peer review, the lack of transparency in charging author fees, no digital archiving policy, etc. ${ }^{15} \mathrm{~A}$ clearly defined policy that promotes high ethical standards and reflects consistent editorial and

${ }^{6}$ James Testa, "The Thomson Reuters Journal Selection Process", IP \& Science - Thomson Reuters (2016), http://wokinfo.com/essays/ journal-selection-process/ (accessed 17 January 2017).

7 Scopus Journal FAQs: Helping to Improve the Submission \& Success Process for Editors \& Publishers (Elsevier, 2014), https://www.elsevier. com/_data/assets/pdf_file/0006/95118/SC_FAQ-content-selection-process-22092014.pdf (accessed 17 January 2017).

8 Edgar L. Feige, "The Consequences of Journal Editorial Policies and a Suggestion for Revision", Journal of Political Economy 83, no. 6 (1 December 1975): 1291-1296, doi:10.1086/260400; Janice M. Beyer, "Editorial Policies and Practices Among Leading Journals in Four Scientific Fields", Sociological Quarterly 19, no. 1 (1 January 1978): 68-88, doi:10.1111/j.1533-8525.1978.tb02172.x.

${ }_{9}$ Inter alia, because this information is important for authors bound by OA mandates.

10 "Copyright Issues in Open Access Research Journals: The Authors' Perspective", D-Lib Magazine 12, no. 2 (2006), http://www.dlib.org/ dlib/february06/vandergraaf/02vandergraaf.html (accessed 15 March 2017); Jeffrey Beall, "Do Most Open-Access Journals Require Copyright Transfer?", Scholarly Open Access (21 July 2016), https://web.archive.org/web/20170113022315/https://scholarlyoa. com/2016/07/21/do-most-open-access-journals-require-copyright-transfer/ (accessed 15 March 2017).

11 "About The Licenses", Creative Commons, https://creativecommons.org/licenses/ (accessed 28 March 2017); Minjeong Kim, "The Creative Commons and Copyright Protection in the Digital Era: Uses of Creative Commons Licenses", Journal of Computer-Mediated Communication 13, no. 1 (1 October 2007): 187-209, doi:10.1111/j.1083-6101.2007.00392.x; Michael W. Carroll, "Creative Commons and the Openness of Open Access", New England Journal of Medicine 368, no. 9 (28 February 2013): 789-791, doi:10.1056/NEJMp1300040.

${ }^{12}$ Heather A. Piwowar and Wendy W. Chapman, "A Review of Journal Policies for Sharing Research Data", in ELPUB2008 (2008), http:// ocs.library.utoronto.ca/index.php/Elpub/2008/paper/view/684 (accessed 28 March 2017).

13 "Principles of Transparency and Best Practice in Scholarly Publishing: Revised and Updated", Committee on Publication Ethics: COPE (2014), http://publicationethics.org/news/principles-transparency-and-best-practice-scholarly-publishing-revised-and-updated (accessed 28 March 2017).

${ }^{14}$ The term "predatory" was invented by Jeffrey Beal, librarian at the University of Denver, Colorado, USA, to designate publishers whose editorial and publishing procedures lacked transparency and who used deceptive strategies to attract manuscript submissions and gain income from the publication fees paid by authors. Beall repeatedly criticized Gold OA as the major source of predatory publishing: Jeffrey Beall, "Predatory Publishing Is Just One of the Consequences of Gold Open Access", Learned Publishing 26, no. 2 (1 April 2013): 79-84, doi:10.1087/20130203

${ }^{15}$ Jeffrey Beall, "Criteria for Determining Predatory Open-Access Publishers (3rd Edition)", Scholarly Open Access (January 2015), https://web.archive.org/web/20150320190303/https://scholarlyoa.files.wordpress.com/2015/01/criteria-2015.pdf (accessed 15 March 2017). 
publishing practices is a reliable way to distinguish OA journals from the so-called "predatory" and suspicious ones.

Most Serbian journals do not have an editorial policy as a distinct document or a codified set of rules. According to local rules and regulations, Serbian journals are not required to have an explicitly defined editorial policy. The Act on Editing Scholarly Journals, ${ }^{16}$ the leading document that defines the standard requirements that local scholarly journals should meet, does not mention the editorial policy as a document, nor is it mentioned in the rules that govern the allocation of subsidies $^{17}$ for scholarly journals. According to the Act, all journals are required to define author guidelines and publish them at least once a year. Some elements (especially a description of the peer review procedure) are sometimes included in author guidelines and they can also be found in the regulations governing the publishing activities of universities, research organizations, cultural institutions, scholarly associations ${ }^{18}$ but the latter documents are rarely publicly available.

\section{Local background}

The practice of introducing an Open Access statement and statements on publication ethics and dealing with misconduct in Serbian journals is fairly recent and is largely associated with a growing number of applications for indexing in Scopus and the reapplication process in DOA).

The former process was additionally boosted by the draft of the Regulation on the Categorization and Ranking of Scholarly Journals, early in 2015 and, again, early in $2016 .{ }^{19}$ According to the draft, SCImago Journal Rank (based on Scopus data) was to be taken into account when ranking Serbian scholarly journals in social sciences and humanities. Although the draft has not been adopted, the provision has been included in the Rule Book on the Procedure and Aspects of Evaluation and Quantitative Expression of Scientific Research Results. ${ }^{20}$ Early in 2015, the national library consortium KoBSON, which is in charge of maintaining the journal repository doiSerbia, ${ }^{21}$ submitted doiSerbia journals for pre-screening in Scopus. This process demonstrated that most journals did not have a statement on publication ethics, which was required by the acceptance criteria. ${ }^{22}$ The journals that strove to be approved for indexing in Scopus usually solved the problem by adopting and adjusting similar statements found in international journals. As the statement was too long to be included in author guidelines, it was added as a separate document, usually as a PDF, only in English and only in the online version.

The purpose of the reapplication process in DOAJ has been to "provide granular information enabling universities, research funders and governments to check journals for compliance with Open Access policy and mandate requirements", as well as to ensure a greater transparency of OA journals. ${ }^{23}$ DOAJ defined new acceptance criteria ${ }^{24}$ and began to apply them in March 2014

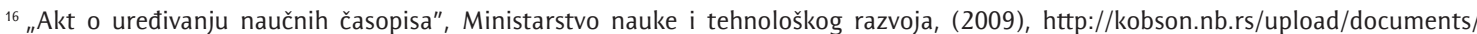
MNTR/Dokumenti/akt_o_uredjivanju_casopisa.pdf (accessed 15 January 2017).

${ }^{17}$ Subsidies provided by the Ministry of Education, Science and Technological Development of the Republic of Serbia.

${ }_{18}$ Most commonly, these documents cover the responsibilities of editors and editorial board members, the peer review procedure and, sometimes, copyright. However, many publishing organizations do not have such documents.

${ }^{19}$ "Pravilnik o kategorizaciji i rangiranju domaćih časopisa: predlog" (2016), http://www.mpn.gov.rs/wp-content/uploads/2015/09/ kategorizacija-\%C4\%8Dasopisa.pdf (accessed 15 January 2017).

20 "Pravilnik o postupku, načinu vrednovanja i kvantitativnom iskazivanju naučnoistraživačkih rezultata istraživača", Službeni glasnik Republike Srbije 24/2016 and 21/2017 (2017), http://www.mpn.gov.rs/wp-content/uploads/2017/03/Pravilnik-2017-preciscen-tekst. pdf (accessed 15 January 2017). The document was adopted in 2016 and amended in 2017.

21 "doiSerbia", Open Access Success Stories (2011), http://www.oastories.org/2011/09/serbia-repository-doiserbia/\#more-16 (accessed 28 December 2016).

22 Scopus Journal FAQs: Helping to Improve the Submission \& Success Process for Editors \& Publishers.

23 "Update on Reapplications and New Applications", DOAJ News Service: News, Updates \& Developments from DOAJ (23 December 2016), https://doajournals.wordpress.com/2016/12/23/update-on-reapplications-and-new-applications/ (accessed 12 January 2017).

${ }^{24}$ DOAJ, "Frequently Asked Questions", https://doaj.org/faq (accessed 26 March 2017).
} 
for new applications, whereas the reapplication of already indexed journals (and their reevaluation against the new criteria) was launched in January 2015. ${ }^{25}$ For 44 doiSerbia journals (out of 55 active), reapplications were managed by KoBSON based on data provided by journal publishers, who were required to fill in a table that contained the 54 questions (not including the contact information) from the DOAJ reapplication form. ${ }^{26}$ Along with general details, journals were required to provide information (and relevant URLs) about their OA statements, submission charges and article processing charges, digital archiving, peer review, the policy of screening for plagiarism, the length of the editorial process, copyright and licensing. It turned out that few journals were able to provide all required pieces of information and that most publishers were not familiar with the concepts of submission charges, article processing charges and Creative Commons licenses. Due to this, the information provided in the reapplication forms was inconsistent and incomplete. ${ }^{27} \mathrm{~A}$ significant number of journals failed to submit the reapplication. As a result, out of 102 Serbian journals indexed in DOAJ before launching the process, more than 40 were removed for various reasons. ${ }^{28}$

\section{Librarians' involvement in devising the editorial policies of $\mathrm{OA}$ journals}

Librarians in Serbia have been involved in the publishing of scholarly journals in many ways. Research librarians are often members of the editorial or technical staff of the journals published by their organizations and they are sometimes able to channel editorial practices through advisory support. KoBSON has generously provided assistance to journals by assigning DOls, enabling $O A$ through the journal repository doiSerbia and delivering metadata about journal articles to various harvesters, ${ }^{29}$ including DOAJ. The DOA) reapplication process revealed that the majority of the publishers of doiSerbia journals were not familiar with the recent developments in OA publishing. In most cases, their response to the new situation was passive: they were not ready to read and analyze the guidelines provided by DOAJ and they expected an instant solution to the problem.

As the deadline for the submission of reapplications was extended on several occasions, ${ }^{30}$ in October 2015, an attempt was made to mitigate the situation by organizing a workshop for doiSerbia journal publishers and offering them a template for the journal policy, in Serbian and English. This first model document covered the elements of publication ethics; a policy of screening for plagiarism; peer review; a retraction policy, an OA statement; including licensing information; self-archiving and copyright, and it enabled journals to meet the requirements defined by DOAJ. As far as copyright was concerned, the template covered only copyright transfer to publishers, as most journals in doiSerbia opted for this solution at that time. ${ }^{31}$ The template was applied by no more than a few doiSerbia journals but it nevertheless reached the journals not included in this platform and was well-received among them. Along with the policy template, a very concise template for author guidelines was also drafted.

\footnotetext{
${ }^{25}$ DOAJ, "DOAJ to Remove Approximately 3300 Journals", DOAJ News Service: News, Updates \& Developments from DOAJ (9 May 2016), https://doajournals.wordpress.com/2016/05/09/doaj-to-remove-approximately-3300-journals/ (accessed 26 March 2017).

${ }^{26}$ DOA), "Journal Application Form", Directory of Open Access Journals (n. d.), https://doaj.org/application/new (accessed 26 March 2017).

${ }^{27}$ Twenty-seven journals failed to provide licensing information. Information is provided by the KoBSON team.

${ }^{28}$ The most common reasons include: failing to submit a reapplication, missing license information, journal not adhering to best practices.

29 "doiSerbia".

${ }^{30}$ DOAJ, "DOAJ to Remove Approximately 3300 Journals".

${ }^{31}$ The preference for copyright transfer in some OA journals in Serbia is explained in detail in Milica Ševkušić et al., Open Access Journals in Serbia: Policies and Practices (Belgrade: National Library of Serbia, 2017).
} 
The guiding idea behind the project Revisiting Open Access Journal Policies and Practices in Serbia, ${ }^{32}$ launched late in March 2016 by the Department of Scientific Information of the National Library of Serbia and funded by EIFL, was to solve or mitigate the problems identified during the prescreening for indexing in Scopus and the DOAJ reapplication process. This time, all journals that had an online version were invited to participate. An important segment of the project was focused on devising an editorial policy template that would address all requirements set out in the DOAJ application criteria and offer a full range of copyright and licensing solutions acceptable in $\mathrm{OA}$ journals. All project team members involved in devising the policy template were librarians.

\section{Identifying policy-related problems}

Unlike the 2015 template, which was limited to the needs and requirements of a group of journals included in doiSerbia, the new template relied on the data collected in an extensive survey, carried out between 30 May and 11 July 2016. The survey results are presented in an extensive study. ${ }^{33}$ For the purpose of this paper, we will cite only the data instrumental in devising the policy template.

The survey captured the following situation:

- all journals covered by the survey provided a list of editorial board members but $36.02 \%$ of them did not provide affiliation information, although this was required by the Act on Editing Scholarly Journals;

- $58.65 \%$ of journals provided neither an OA statement nor any indication of their OA status;

- nearly $90 \%$ of the respondents did not charge submission charges but in most journals this was not explicitly stated;

- more than $85 \%$ of the respondents did not charge article processing charges (APCs), but in most cases, this information was impossible to find on the journal's website;

- few journals charged submission charges and/or APCs and only some of them explicitly stated this on their websites;

- $85.17 \%$ of journals provided author guidelines on their websites;

- in nearly $40 \%$ of journals, no information about the peer review process could be found;

- $61.44 \%$ of journals did not provide information about the average length of the review procedure;

- more than $50 \%$ the respondents did not provide information regarding the type of peer review;

- although the Act on Editing Scholarly Journals explicitly required that only papers that had received two positive reviews merit publication, in nearly $20 \%$ of journals, each paper was reviewed by a single reviewer or was evaluated by the editor or an editorial board member, and this was not explicitly stated;

- in some journals, invited and conference papers were exempt from the regular peer review procedure and this was not explicitly stated;

- $72.03 \%$ of journals had neither a policy on publication ethics nor elements of it included in other documents (e.g. author guidelines);

- $62.71 \%$ of the respondents did not use any plagiarism detection software and less than $10 \%$ of journals explicitly stated that plagiarism was unacceptable;

- in $84.32 \%$ of journals it was impossible to find elements of a policy for dealing with misconduct;

32 "Revisiting Open Access Journal Policies and Practices in Serbia", EIFL (8 April 2016), http://www.eifl.net/news/revisiting-openaccess-journal-policies-and-practices-serbia (accessed 26 March 2017).

${ }^{33}$ The survey covered both policy-related issues and editorial and publishing practices and was responded by $236 \mathrm{OA}$ journals. - Milica Ševkušić et al., Open Access Journals in Serbia: Policies and Practices. Unless otherwise stated, all quantitative data are taken from this study. 
- $89.41 \%$ of journals did not have an explicitly defined retraction policy, though some of them had published retractions;

- in $46.61 \%$ of journals rights were not defined and $21.19 \%$ of the respondents provided ambiguous or otherwise invalid responses;

- only $19.07 \%$ of journals used Creative Commons licenses and had the license information on their websites, and only $6 \%$ of the analyzed journals marked each paper with the appropriate license;

- $77.12 \%$ of journals did not have an explicitly defined self-archiving policy.

Beyond the quantitative data, the responses showed that:

- most journals enabled immediate and unrestricted access to their content but did not find it necessary to state this explicitly;

- the concepts of submission charges and APCs (i.e. author charges) were not clear to a significant number of respondents;

- in some journals, the payment of author charges was not done transparently;

- copyright and licensing awareness was generally poor, as indicated by a large number of unreliable and illogical responses;

- a significant share of editors and publishers involved in the project found it difficult to understand and implement Creative Commons licenses.

The survey data showed that in most Serbian OA journals the information provided to readers and potential authors was incomplete. In other words, authors were expected to submit a manuscript without knowing whether it would be peer reviewed or not, whether APCs would be charged, whether copyright transfer would be required, whether reuse would be allowed, etc. In order to meet the requirements set out by DOAJ, journals had to add all of the missing pieces of information to their websites. Most journals provided author guidelines but it was impossible to include all of the above-mentioned information in it in a straightforward way. As the website structures varied and many journals ${ }^{34}$ did not have their own websites but the content was uploaded on the sites of the publishing institutions, it was apparent that the optimal (and the only feasible) solution would be to devise a single document that would include the relevant information and offer it to journals.

\section{Policy sources and guidelines}

The body of sources that served as guidance in developing the editorial policy template principally included the materials provided by the Committee on Publication Ethics (COPE), ${ }^{35}$ the guidelines for applicants provided by DOA $)^{36}$ and Open Access Scholarly Publishers Association (OASPA), ${ }^{37}$ the Act on Editing Scholarly Journals ${ }^{38}$ and the editorial policies of individual OA journals. The guidelines provided by COPE were particularly useful in defining policies associated with publication ethics and misconduct, including plagiarism, as well as retraction policies and procedures. DOAJ Information for Publishers provided valuable information about copyright and licensing. However, the most important sources for this segment of the policy were copyright and licensing policies of individual OA journals and blogs on OA. ${ }^{39}$

While discipline-specific guidelines (such as the Recommendations for the Conduct, Reporting, Editing and Publication of Scholarly Work in Medical Journals of the International Committee

\footnotetext{
${ }^{34}$ According to the survey, about $40 \%$ of the analyzed journals did not have their own websites, Ibid.

${ }^{35}$ Committee on Publication Ethics: COPE, "Guidelines", http://publicationethics.org/resources/guidelines (accessed 30 March 2017).

${ }^{36}$ DOAJ, "Information for Publishers", Directory of Open Access Journals, https://doaj.org (accessed 7 January 2017).

37 "Licensing FAQ", OASPA, http://oaspa.org/information-resources/frequently-asked-questions/ (accessed 30 March 2017).

${ }^{38}$ "Akt o uređivanju naučnih časopisa".

${ }^{39}$ Heather Morrison, "Creative Commons and Open Access Critique Series", The Imaginary Journal of Poetic Economics, http:// poeticeconomics.blogspot.com/2012/10/critique-of-cc-by-series.html (accessed 30 March 2017).
} 
of Medical Journal Editors ${ }^{40}$ or the Ethical Principles of Psychologists and Code of Conduct ${ }^{41}$ ) were consulted, the policy model was developed along general lines. Discipline-specific provisions were not included in the template but journal publishers were advised to include or use them instead of the proposed provisions whenever appropriate.

\section{Template for the editorial policy of Open Access journals}

The policy template is a document that contains predefined text that can easily be adjusted by inserting the name of the journal, adding provisions relevant for a particular journal or discipline, and deleting inapplicable provisions. ${ }^{42}$ It is supplied with explanations, provided in footnotes, which should be deleted once the process of defining the policy is completed. The template contains the following sections:

- a brief introduction (largely corresponding to Aims and Scope),

- editorial responsibilities:

- the responsibilities of the editor and the editorial board;

- the responsibilities of authors (including reporting standards, authorship, acknowledgment of sources, plagiarism, conflict of interest, fundamental errors in published works);

- the responsibilities of reviewers;

- peer review (including the review type, the number of reviewers and the length of the procedure);

- procedures for dealing with unethical behaviour (investigation, minor misconduct, major misconduct);

- retraction policy;

- an OA statement (including license information);

- submission charges and article processing charges;

- self-archiving policy;

- copyright (including license information);

- a standard disclaimer. ${ }^{43}$

The structure of the template is modular. The order of individual sections can be changed and each section may be extended (e.g. by inserting discipline-specific provisions) so as to form a distinct unit, i.e. a separate page on the website. The project team provided assistance to journal publishers throughout the process of aligning journal policies. All publishers could send their drafts to the project team for revision.

The information normally contained under Aims and Scope is usually available in Serbian journals at various places (website, home page, a separate page within the website, author guidelines, editorials, etc). The policy template leaves it to journal publishers to define aims and scope as they find it appropriate. On the other hand, it is recommended to provide - in the introductory section - the information about the languages used in the journal, publication frequency, indexing and abstracting and digital archiving. ${ }^{44}$

${ }^{40}$ ICMJE, "Recommendations for the Conduct, Reporting, Editing, and Publication of Scholarly Work in Medical Journals", ICMJE, 2016, http://www.icmje.org/news-and-editorials/icmje-recommendations_annotated_dec16.pdf (accessed 30 March 2017).

${ }^{41}$ American Psychological Association, "Ethical Principles of Psychologists and Code of Conduct", American Psychological Association, http://www.apa.org/ethics/code/ (accessed 30 March 2017).

${ }^{42}$ The English and Serbian versions of the template are available online and can be downloaded and used free of charge without asking permission: https://goo.gl/ixgoEN, https://goo.gl/ZrLNCw (accessed 30 March 2017).

${ }^{43}$ The editorial policy template does not deal with the list of editorial board members. As it has been demonstrated, this information is generally available in Serbian journals. The problem of missing and inconsistent affiliations was addressed in workshops organized during the project.

${ }^{44}$ The digital content of all journals published in Serbia is archived by the National Library of Serbia (legal deposit for digital content and the Digital Repository of the National Library of Serbia) and the Matica Srpska Library (legal deposit for digital content). Some journals are also archived by SCIndeks. Several journals use LOCKSS. 
The sections dealing with responsibilities, peer review, procedures for dealing with unethical behaviour and the retraction policy largely rely on the COPE guidelines. In the process of defining journal policies, Serbian journal publishers generally adopted the proposed text of these sections. Judging by the questions raised during consultations with the project team, it seems that they understood the purpose of the proposed provisions very well. Some of them found it necessary to adjust the text by including provisions that addressed problems encountered in their previous work (e.g. specific types of misconduct not mentioned in the template) or references to discipline-specific codes and standards, and this was generally done successfully. Although the DOAJ application form allows to choose among "editorial review", "peer review", "blind peer review", "double blind peer review" and "none", the possibilities offered in the template include single-blind and double-blind peer review. The concept of open peer review is introduced in the notes and explanations, though no journals in Serbia use this type of review. The Act on Editing Scholarly Journals stipulates only double-blind peer review. However, the survey data show that $26.69 \%$ of journals in Serbia use a single-blind procedure. Therefore, it was necessary to provide guidance for these journals, as well. Editorial review ${ }^{45}$ is not included in the template because the Act explicitly requires that each paper be reviewed by at least two reviewers and that only papers that receive two positive reviews may be accepted for publication. As far as the policy of screening for plagiarism, procedures for dealing with misconduct and the retraction policy are concerned, the practices tracked by the survey suggest that some journals might be inconsistent when it comes to their implementation. ${ }^{46}$

The template proposes a short OA statement accompanied with license terms. ${ }^{47}$ Publishers are free to choose one of the Creative Commons licenses. Most journals adopted the proposed statement but it was still possible to find those where only the first part of the statement was adopted, while the license information was removed.

Submission charges and article processing charges are extensively covered in the template, though few journals in Serbia charge author fees and, according to the survey data, the vast majority of OA journals will remain APC-free. ${ }^{48}$ The responses provided in the survey also show that the information about author fees is not always transparent. Furthermore, some journals do not issue a receipt to the payees and seek to disguise the APC under the terms such as "donation" or "membership fee". Detailed explanations are offered with the idea of rectifying the bad practices and providing sound guidance to those who might decide to introduce author fees. The template makes a distinction between submission charges and article processing charges, where the former are charged at submission and the latter upon the acceptance of a manuscript. Basic instructions relating to a waiver policy are also provided. Author fees in Serbian journals are generally rather low, ${ }^{49}$ compared to the international average..$^{50}$ Nevertheless, APC-charging journals are ready to waive costs and it is noteworthy that they have various approaches to this issue: some waive APCs to local authors, whereas others charge only local authors because they seek to attract the international ones.

\footnotetext{
${ }^{45}$ DOAJ accepts editorial review only in Arts and Humanities journals. - DOA), "Information for Publishers".

${ }^{46}$ For more information see Ševkušić et al., Open Access Journals in Serbia: Policies and Practices.

${ }^{47}$ DOAJ, "Information for Publishers".

${ }^{48}$ Milica Ševkušić et al., "7. 4. Submission Charges and 12. Article Processing Charges", in Open Access Journals in Serbia: Policies and Practices.

${ }^{49}$ According to Crawford (Walt Crawford, The Countries of OAWorld: 2011-2015 (Livermore, CA: Cites \& Insights Books, 2016), 133, http://waltcrawford.name/goajcntr.pdf, (accessed 30 March 2017)), the average APC in Serbian APC-charging journals indexed in DOAJ was 395 USD. In the journals covered by the survey, author fees were not higher than 300 EUR. - Milica Ševkušić et al., Open Access Journals in Serbia: Policies and Practices.

${ }^{50}$ Average APCs are approximately $€ 1,500$ (Gold-APC) and $€ 2,500$ (Gold-Hybrid). Rob Johnson et al., "Towards a Competitive and Sustainable OA Market in Europe - A Study of the Open Access Market and Policy Environment", OpenAIRE, Research Consulting (2017), 5, https://blogs.openaire.eu/wp-content/uploads/2017/03/OA-market-report-28Final-13-March-201729-1.pdf (accessed 30 March 2017).
} 
The proposed self-archiving policy offers to publishers three possibilities: to allow authors to upload on a website or deposit in a repository a pre-print (a manuscript that has not been subject to peer-review), a post-print (the peer-reviewed version of a manuscript, accepted for publication) and the final, published version of an article (publisher's PDF)..$^{51}$ Allowing authors to deposit pre-final versions may increase the impact of open access, as readers are able to access content and use it earlier. Most Serbian OA journals have decided to allow authors to deposit only the published version, which, accompanied with the sub-optimal publishing schedules and practices, ${ }^{52}$ delays the potential impact of the presented research results. Nevertheless, the majority of journal publishers in Serbia are not ready to let manuscripts that have not been subject to copyediting appear in public..$^{53}$ On the other hand, they often encourage authors to upload the published versions on social networking sites, such as ResearchGate and Academia.edu.

The copyright and licensing sections of the policy template were the most difficult to define and these policy provisions will probably be the most difficult to carry out in practice. At the same time, this was the area where librarians' skills and competencies were most required. The main dilemma was whether to define a single "optimal" solution for copyright and licensing or let publishers choose among the full range of acceptable solutions. The major risk associated with the former option was potential refusal on the part of some publishers to comply with such a policy. The body of Serbian OA journals is diversified, ranging from those unaware of their OA status and relying on the practices typical of print journals, to those where good OA practices have been fully understood and adopted. A single solution could not meet the needs of all of them. On the other hand, the latter option engendered the risk of making the choice too difficult to make, having in mind the overall lack of copyright awareness among Serbian journal publishers detected in the survey. The project team eventually adopted the latter approach. The template offers the following three options:

- authors transfer copyright to the publisher;

- authors retain copyright and grant to the publisher the non-exclusive right to publish the article;

- authors retain both copyright and publishing rights.

In all cases, Creative Commons licenses are used, as they are recommended as standard by DOAJ. ${ }^{54}$ Journals may decide to publish all articles under the same Creative License or let authors choose the license module. The offered possibilities cover the solutions already applied in Serbian OA journals and those seen as acceptable by journal publishers. An early version of the template allowed for granting to publishers an exclusive right to publish, while authors retained copyright, because such an approach could be found in OA journals. It was later decided to remove it from the template as a practice that is contrary to the spirit of OA. ${ }^{55}$

For a number of Serbian journal publishers Creative Commons licenses are "complicated", though they have been present in the local research community, especially after the establishment of the PHAIDRA Digital Repository of the University Library in Belgrade. ${ }^{56}$ The following problems are typically encountered:

\footnotetext{
${ }^{51}$ For full definitions of article versions see "SHERPA RoMEO Colours, Pre-Print, Post-Print: Definitions and Terms", SHERPA (2006), http://www.sherpa.ac.uk/romeoinfo.html (accessed 25 January 2017).

52 The topic is extensively discussed in Milica Ševkušić et al., "7. 3. Online publishing" and "9. Editorial process", in Open Access Journals in Serbia: Policies and Practices.

${ }^{53}$ Milica Ševkušić et al., "8.3. Rights retained by authors and the self-archiving policy", in Open Access Journals in Serbia: Policies and Practices.

${ }^{54}$ DOA), "Information for Publishers".

${ }^{55}$ Heather Morrison, "Author Copyright in Name Only", The Imaginary Journal of Poetic Economics (22 May 2015), http://poeticeconomics. blogspot.com/2015/05/author-copyright-in-name-only.html (accessed 5 March 2017).

${ }^{56}$ Dragana Stolic et al., "Establishing Digital Repositories at Western Balkan Universities" (paper presented in INFORUM 2012: 18th Annual Conference on Professional Information Resources, Prague, Czech Republic, 2012), http://www.inforum.cz/proceedings/2012/25/ (accessed 27 March 2017).
} 
- there is a widespread misconception that uses that are not explicitly forbidden are actually allowed; due to this, some publishers see no need to use licenses;

- journal publishers do not understand the distinction between copyright and user rights - if they have defined the copyright holder, they do not find it necessary to define the license terms and vice versa;

- some publishers do not understand the core conditions of Creative Commons licenses and their combinations;

- a significant number of publishers find it "inconvenient" to add license information to all articles.

This raises serious concerns regarding the implementation of Creative Commons licenses in journals. Despite clear instructions and training, already during the process of aligning editorial policies it was possible to observe practices that put journals at risk of being identified as "suspicious" due to the "poor understanding of licensing standards"57 - e.g. a Creative Commons license mark and an "all rights reserved" sign could be found in the same article or different license modules were used in the editorial policy and articles. ${ }^{58}$

Along with the policy template, the project team developed a set of templates for license agreements, the author statement and author guidelines. The three license agreement templates correspond to the three copyright options covered in the policy template (copyright transfer, authors retain copyright, authors retain both copyright and publishing rights). The author statement is increasingly often required by Serbian OA journals as an aid in establishing the responsibility in case of misconduct. In this document, authors confirm the authorship of the submitted paper, declare the conflict of interest or its absence, state that the manuscript was not submitted for publication in another journal, etc. ${ }^{59}$ The template covers only the most typical situations and publishers may amend it to fit their needs. As most journals already have instructions for authors and these documents greatly vary for journals that belong to various areas of research, the template for author guidelines is simple and it contains only the hints on the topics that need to be covered.

\section{Conclusion}

During the implementation of the project Revisiting Open Access Journal Policies and Practices in Serbia it was possible to identify various topics where librarians were able to provide assistance to OA journals publishers. The most important ones include:

- digital legal deposit and digital archiving;

- raising awareness on the standards of electronic publishing;

- raising awareness about the importance of article-level metadata;

- education on publication ethics and good OA practices;

- raising awareness about the importance of editorial policies;

- defining and implementing editorial policies;

- explaining the requirements that journals need to meet in order to qualify for indexing in major indexing databases and services (e.g. Web of Science, Scopus, DOAJ).

This type of involvement was possible owing to specific competencies developed in performing everyday duties of research librarians - the interaction with researchers in the process of providing support to research activities, training on information literacy and research integrity, and advising researchers how to select journals to publish in.

\footnotetext{
${ }^{57}$ Jeffrey Beall, "Criteria for Determining Predatory Open-Access Publishers (3 ${ }^{\text {rd }}$ Edition)".

${ }^{58}$ Milica Ševkušić et al., Open Access Journals in Serbia: Policies and Practices.

${ }^{59} \mathrm{All}$ of the templates are available online http://repozitorijum.nb.rs/kutakzaurednike.aspx?upustvo=5 (accessed 23 March 2017).
} 
One of the most important achievements ${ }^{60}$ of the project is the template for the editorial policy of Open Access journals. It enables journals to meet all of the policy-related requirements set out by DOAJ, which is confirmed by the fact that practically all journals that defined their editorial policies relying on the offered template have successfully passed the reapplication procedure in DOA). ${ }^{61}$

The process of aligning editorial policies was accompanied with some problems. As they are extensively discussed in the above-mentioned study, the attention will be drawn only to the most challenging ones. A number of Serbian OA publishers are prone to improvising even when straightforward solutions are offered. The offered guidelines are sometimes implemented selectively, in a piecemeal fashion: publishers feel free to remove from the template whatever they consider unimportant (or perhaps do not understand) regardless of the actual importance of the removed provisions. Some editors are more likely to follow the misleading advice of their colleagues (other editors) than to accept the guidance provided by librarians. Such an approach may be associated with the generally unfavourable status of librarians in Serbia. However, the most severe problem at the policy level, and the greatest challenge for the future, is the poor understanding of copyright and licensing, which may seriously threaten the implementation of the defined policies.

The situation regarding the implementation of copyright and licensing policies in Serbian $O A$ journals reflects the generally poor understanding of copyright and licensing in the local research community. Local OA publishers are principally academic institutions, research organizations and scholarly societies. Their budgets are poor and they cannot afford legal advisors but they could find convenient assistance in libraries. Librarians' activities involve various copyright-related issues (e.g. permissions and copyright clearance, OA publishing, publishers' agreements $)^{62}$ and the knowledge of copyright and licensing is particularly required in the libraries that maintain institutional repositories. ${ }^{63}$ Although librarians in Serbia do not get appropriate training for dealing with copyright and licensing, there is a body of professionals ${ }^{64}$ able to provide relevant advisory assistance both to their colleague librarians and to journal publishers/editors. The need for strengthening the copyright literacy of librarians has been identified in various environments. ${ }^{65}$ The commonly recommended measures aimed at improving the copyright competencies include the revision of Library and Information Science curricula and other education programmes for librarians so as to include training on copyright and licensing, especially in an Open Access context. This would empower librarians to engage more actively in improving the copyright literacy within the research community, including journal editors and other editorial staff members.

\footnotetext{
${ }^{60}$ The project results also include an extensive study offering insight into the policies and practices of Serbian OA journals (Milica Ševkušić et al., Open Access Journals in Serbia: Policies and Practices), a website where all materials (a set of guidelines and video recordings of workshops) created during the project are made available (http://repozitorijum.nb.rs/kutakzaurednike.aspx?upustvo=5), and the upgraded doiSerbia platform (the journals included in the platform may upload their editorial policies and author guidelines there).

${ }^{61}$ About 35 journals, so far. It is estimated that about one hundred journals defined their editorial policies during the project.

${ }^{62}$ Inga-Lill Nilsson, "Developing New Copyright Services in Academic Libraries", Insights 29, no. 1 (7 March 2016), doi:10.1629/uksg.276.

${ }^{63}$ Ann Hanlon and Marisa Ramirez, "Asking for Permission: A Survey of Copyright Workflows for Institutional Repositories", Portal: Libraries and the Academy 11, no. 2 (5 June 2011): 683-702, doi:10.1353/pla.2011.0015.

${ }^{64}$ These are principally repository managers and librarians involved in digitization projects.

${ }^{65}$ Tania Todorova et al., "A Multinational Study on Copyright Literacy Competencies of LIS Professionals", in Information Literacy. Lifelong Learning and Digital Citizenship in the 21st Century (European Conference on Information Literacy, Springer, Cham, 2014), 138-148, doi:10.1007/978-3-319-14136-7_15; Chris Morrison and Jane Secker, "Copyright Literacy in the UK: A Survey of Librarians and Other Cultural Heritage Sector Professionals", Library and Information Research 39, no. 121 (22 December 2015): 75-97; Deborah H. Charbonneau and Michael Priehs, "Copyright Awareness, Partnerships, and Training Issues in Academic Libraries", The Journal of Academic Librarianship 40, no. 3-4 (May 2014): 228-233, doi:10.1016/j.acalib.2014.03.009.
} 


\section{References and sources:}

1. "About The Licenses". Creative Commons. https://creativecommons.org/licenses/ (accessed 28 March 2017).

2. „Akt o uređivanju naučnih časopisa”. Ministarstvo nauke i tehnološkog razvoja. 2009. http://kobson. nb.rs/upload/documents/MNTR/Dokumenti/akt_o_uredjivanju_casopisa.pdf (accessed 15 January 2017).

3. American Psychological Association. "Ethical Principles of Psychologists and Code of Conduct". American Psychological Association. http://www.apa.org/ethics/code/ (accessed 30 March 2017).

4. Beall, Jeffrey. "Criteria for Determining Predatory Open-Access Publishers ( $3^{\text {rd }}$ Edition)". Scholarly Open Access (January 2015). https://web.archive.org/web/20150320190303/https://scholarlyoa.files. wordpress.com/2015/01/criteria-2015.pdf (accessed 15 March 2017).

5. Beall, Jeffrey. "Do Most Open-Access Journals Require Copyright Transfer?". Scholarly Open Access (21 July 2016). https://web.archive.org/web/20170113022315/https://scholarlyoa.com/2016/07/21/domost-open-access-journals-require-copyright-transfer/ (accessed 15 March 2017).

6. Beall, Jeffrey. "Predatory Publishing Is Just One of the Consequences of Gold Open Access". Learned Publishing 26, no. 2 (1 April 2013): 79-84. doi:10.1087/20130203.

7. Beyer, Janice M. "Editorial Policies and Practices Among Leading Journals in Four Scientific Fields". Sociological Quarterly 19, no. 1 (1 January 1978): 68-88. doi:10.1111/j.1533-8525.1978.tb02172.x.

8. Carroll, Michael W. "Creative Commons and the Openness of Open Access". New England Journal of Medicine 368, no. 9 (28 February 2013): 789-791. doi:10.1056/NEJMp1300040.

9. Charbonneau, Deborah H. and Michael Priehs. "Copyright Awareness, Partnerships, and Training Issues in Academic Libraries". The Journal of Academic Librarianship 40, no. 3-4 (May 2014): 228-233. doi:10.1016/j.acalib.2014.03.009.

10. Committee on Publication Ethics: COPE. "Guidelines". http://publicationethics.org/resources/ guidelines (accessed 30 March 2017).

11. "Copyright Issues in Open Access Research Journals: The Authors' Perspective". D-Lib Magazine 12, no. 2 (2006). http://www.dlib.org/dlib/february06/vandergraaf/02vandergraaf.html (accessed 15 March 2017).

12. Crawford, Walt. The Countries of OAWorld: 2011-2015. Livermore, CA: Cites \& Insights Books, 2016. http://waltcrawford.name/goajcntr.pdf (accessed 30 March 2017).

13. DeBakey, Lois. The Scientific Journal: Editorial Policies and Practices: Guidelines for Editors, Reviewers, and Authors. C. V. Mosby Co., 1976.

14. DOAJ. "DOAJ to Remove Approximately 3300 Journals". DOAJ News Service: News, Updates \& Developments from DOAJ. 9 May 2016. https://doajournals.wordpress.com/2016/05/09/doaj-to-removeapproximately-3300-journals/ (accessed 26 March 2017).

15. DOAJ. "Frequently Asked Questions". https://doaj.org/faq (accessed 26 March 2017).

16. DOAJ. "Information for Publishers". Directory of Open Access Journals. https://doaj.org (accessed 7 January 2017).

17. DOAJ. "Journal Application Form". Directory of Open Access Journals. N. d. https://doaj.org/application/ new (accessed 26 March 2017).

18. "doiSerbia". Open Access Success Stories. 2011. http://www.oastories.org/2011/09/serbia-repositorydoiserbia/\#more-16 (accessed 28 December 2016).

19. Feige, Edgar L. "The Consequences of Journal Editorial Policies and a Suggestion for Revision". Journal of Political Economy 83, no. 6 (1 December 1975): 1291-1296. doi:10.1086/260400.

20. Hanlon, Ann, and Marisa Ramirez. "Asking for Permission: A Survey of Copyright Workflows for Institutional Repositories". Portal: Libraries and the Academy 11, no. 2 (5 June 2011): 683-702. doi:10.1353/pla.2011.0015.

21. ICMJE. "Recommendations for the Conduct, Reporting, Editing, and Publication of Scholarly Work in Medical Journals". ICMJE. 2016. http://www.icmje.org/news-and-editorials/icmje-recommendations_ annotated_dec16.pdf (accessed 30 March 2017). 
22. Johnson, Rob, Mattia Fosci, Andrea Chiarelli, Stephen Pinfield, and Michael Jubb. "Towards a Competitive and Sustainable OA Market in Europe - A Study of the Open Access Market and Policy Environment". OpenAIRE, Research Consulting. 2017. https://blogs.openaire.eu/wp-content/ uploads/2017/03/OA-market-report-28Final-13-March-201729-1.pdf (accessed 30 March 2017).

23. Kim, Minjeong. "The Creative Commons and Copyright Protection in the Digital Era: Uses of Creative Commons Licenses". Journal of Computer-Mediated Communication 13, no. 1 (1 October 2007): 187-209. doi:10.1111/j.1083-6101.2007.00392.x.

24. "Licensing FAQ". OASPA. http://oaspa.org/information-resources/frequently-asked-questions/ (accessed 30 March 2017).

25. Morrison, Chris, and Jane Secker. "Copyright Literacy in the UK: A Survey of Librarians and Other Cultural Heritage Sector Professionals". Library and Information Research 39, no. 121 (22 December 2015): 75-97.

26. Morrison, Heather. "Author Copyright in Name Only". The Imaginary Journal of Poetic Economics (22 May 2015). http://poeticeconomics.blogspot.com/2015/05/author-copyright-in-name-only.html (accessed 5 March 2017).

27. Morrison, Heather. "Creative Commons and Open Access Critique Series". The Imaginary Journal of Poetic Economics. http://poeticeconomics.blogspot.com/2012/10/critique-of-cc-by-series.html (accessed 30 March 2017).

28. Nilsson, Inga-Lill. "Developing New Copyright Services in Academic Libraries". Insights 29, no. 1 (7 March 2016). doi:10.1629/uksg.276.

29. Piwowar, Heather A. and Wendy W. Chapman. "A Review of Journal Policies for Sharing Research Data". In ELPUB2008. 2008. http://ocs.library.utoronto.ca/index.php/Elpub/2008/paper/view/684 (accessed 28 March 2017).

30. „Pravilnik o kategorizaciji i rangiranju domaćih časopisa: predlog”. 2016. http://www.mpn.gov.rs/wpcontent/uploads/2015/09/kategorizacija-\%C4\%8Dasopisa.pdf (accessed 15 January 2017).

31. „Pravilnik o postupku, načinu vrednovanja i kvantitativnom iskazivanju naučnoistraživačkih rezultata istraživača". Službeni glasnik Republike Srbije 24/2016 and 21/2017 (2017). http://www.mpn.gov.rs/wpcontent/uploads/2017/03/Pravilnik-2017-preciscen-tekst.pdf (accessed 15 January 2017).

32. "Principles of Transparency and Best Practice in Scholarly Publishing: Revised and Updated". Committee on Publication Ethics: COPE. 2014. http://publicationethics.org/news/principles-transparencyand-best-practice-scholarly-publishing-revised-and-updated (accessed 28 March 2017).

33. "Revisiting Open Access Journal Policies and Practices in Serbia". EIFL. 8 April 2016. http://www.eifl. net/news/revisiting-open-access-journal-policies-and-practices-serbia (accessed 26 March 2017).

34. Scopus Journal FAQs: Helping to Improve the Submission \& Success Process for Editors \& Publishers. Elsevier. 2014. https://www.elsevier.com/_data/assets/pdf_file/0006/95118/SC_FAQ-content-selectionprocess-22092014.pdf (accessed 17 January 2017).

35. Ševkušić, Milica, Zorica Janković, and Aleksandra Kužet. Open Access Journals in Serbia: Policies and Practices. Belgrade: National Library of Serbia, 2017.

36. "SHERPA RoMEO Colours, Pre-Print, Post-Print: Definitions and Terms". SHERPA. 2006. http://www. sherpa.ac.uk/romeoinfo.html (accessed 25 January 2017).

37. Stolic, Dragana, Gordana Mazic, and Bogoljub Mazic. "Establishing Digital Repositories at Western Balkan Universities". Paper presented in INFORUM 2012: 18th Annual Conference on Professional Information Resources, Prague, Czech Republic, 2012. http://www.inforum.cz/proceedings/2012/25/ (accessed 27 March 2017).

38. Testa, James. "The Thomson Reuters Journal Selection Process". IP \& Science - Thomson Reuters. 2016. http://wokinfo.com/essays/journal-selection-process/ (accessed 17 January 2017).

39. Todorova, Tania, Tereza Trencheva, Serap Kurbano lu, Güleda Do an, Aleksandra Horvat, and Joumana Boustany. "A Multinational Study on Copyright Literacy Competencies of LIS Professionals". In Information Literacy. Lifelong Learning and Digital Citizenship in the $21^{\text {st }}$ Century, 138-148. European Conference on Information Literacy, Springer, Cham, 2014. doi:10.1007/978-3-319-14136-7_15. 
40. "Update on Reapplications and New Applications". DOAJ News Service: News, Updates \& Developments from DOAJ. 23 December 2016. https://doajournals.wordpress.com/2016/12/23/update-onreapplications-and-new-applications/ (accessed 12 January 2017).

41. Weller, A C. "Editorial Policy and the Assessment of Quality among Medical Journals". Bulletin of the Medical Library Association 75, no. 4 (October 1987): 310-316.

\title{
Дефинисање уређивачких политика часописа у отвореном приступу у Србији и улога библиотекара у том процесу
}

\begin{abstract}
Сажетак
У раду се разматра процес креирања модела уређивачке политике намењеног домаћим часописима у отвореном приступу и улога библиотекара у том процесу. Модел (образац) је документ који садржи предлог текста уређивачке политике дефинисан тако да задовољи све критеријуме у вези са уређивачком политиком које утврђују база података Directory of Open Access J ournals, као и цитатни индекси Web of Science и Scopus. Структура обрасца је модуларна, а основни тематски блокови које покрива обухватају етичка питања у издаваштву, уређивање часописа и објављивање радова, као и ауторска права и права коришћења. Важну улогу у дефинисању обрасца имала су стручна знања која су чланови пројектног тима развили кроз рад у библиотекама научних установа. Библиотекари су пружили и техничку подршку у процесу дефинисања уређивачких политика домаћих часописа, односно у процесу њиховог усклађивања са понуђеним моделом. Један од првих резултата наведених акција јесте успешан исход поступка реапликације у бази података Directory of Open Access J ournals за све часописе који су дефинисали уређивачку политику ослањајући се на понуђени образац. Процес дефинисања уређивачких политика домаћих часописа указао је на одређене проблеме, као што су селективна примена препорука, ослањање на непроверене информације које долазе од колега, уз истовремено занемаривање савета библиотекара, и, нарочито, непознавање и неразумевање основних појмова који се односе на ауторска права и права коришћења. Последњи наведени проблем, који одражава слабо развијену свест о ауторским правима у домаћој научној заједници, могао би да доведе у питање спровођење дефинисаних уређивачких политика. Имајући у виду непрофитни карактер и скромне буџете научних часописа из Србије, ангажовање правника који би помогли у решавању поменутог проблема није могуће. Проблем би се могао решити укључивањем библиотекара у едукацију припадника домаће научне заједнице о ауторским правима, нарочито у контексту отвореног приступа, а неопходан предуслов за то јесте унапређивање стучних способности самих библиотекара кроз осавремењивање курикулума и перманентну едукацију.
\end{abstract}

Кључне речи: часописи у отвореном приступу, Србије, уређивачка политика, Directory of Open Access Journals (DOAJ), Committee on Publication Ethics, научна рецензија, ауторска права, Creative Commons лиценце, такса за објављивање у отвореном приступу

Примљено: 1. априла 2017. Исправке рукописа: 17. априла 2017. Прихваћено за објављивање: 23. априла 2017. 